\title{
O PODER DO CIDADÃO EM PORTO ALEGRE
}

Margarete Panerai Araújo*

SÍNTESE - Este artigo visa demonstrar como se vem instaurando a formação do cidadão através do Orçamento Participativo (O.P.), na cidade de Porto Alegre, após 1990.

PALAVRAS-CHAVE - orçamento participativo, formação/práticas formativas, cidadão.
ABSTRACT - This article aims to demonstrate how the formation of citizens has been established through the Participatory Budget (O.P.) in the city of Porto Alegre, after 1990.

KEY WORDS - participatory budget, formation/ formative practices, citizen.

\section{Introdução}

O Orçamento Participativo, sistema de administração dos recursos públicos de investimentos, tem-se constituido, nos últimos dez anos, num espaço propício à instauração da formação do cidadão.

A pesquisa, em desenvolvimento, pretende averiguar como se constrói o processo de formação do cidadão, a partir das seguintes premissas:

- a implantação do Orçamento Participativo pela Administração Popular desencadeou a participação do povo na gestão pública;

- os segmentos populares, através de instâncias de decisão como o Conselho do Orçamento Participativo, passam a dispor de novos espaços e de poder político, construindo uma visão globalizadora quanto à própria formação.

\section{Implantação do Orçamento Participativo}

O Orçamento Participativo (O.P.) instituído pela Prefeitura de Porto Alegre, em 1989, por Lei Complementar e Decreto assinado em 1988, desencadeou rupturas sociais, pois a gestão popular instaura procedimentos e iniciativas não praticados até então pelos governos municipais anteriores e que canalizam recursos públicos para políticas sociais. O processo do Orçamento Participativo é constituído de um sistema administrativo de planejamento composto por dezesseis fóruns regionais e cinco temáticos, tendo como meta principal incentivar os segmentos populares a

* Socióloga, mestranda em Serviço Social, bolsista da Ccordenação de Aperfeiçoamento de Pessoal de Nivel Superior - CAPES

\begin{tabular}{|l|l|l|l|l|l|}
\hline VERITAS & Porto Alegre & v. 43 & $\mathrm{n}^{0}$ especial & Dezembro 1998 & p. $45-47$ \\
\hline
\end{tabular}


deliberarem, de forma organizada, sobre os investimentos previstos para o conjunto da cidade.

Nessa perspectiva, a dimensão marcante está na participação do povo junto ao governo municipal através dos Conselhos Populares, fiscalizando e definindo, em assembléias comunitárias, as reivindicações e prioridades para cada região. Este sistema administrativo, instaurado há uma década, torna-se um instrumento símbolo de Porto Alegre, pois suas técnicas contribuem para esboçar um novo perfil do cidadão, baseado nas relações sociais. Tais relações vividas pelos agentes que participam das reuniões desencadeiam-se num campo de forças em que há posições bastante claras e no qual as decisões são amplamente disputadas. Neste sentido, o que resulta são relações de força simbólicas ${ }^{1}$ que se manifestam estrategicamente e, à medida que esse aparelho de mobilização se fortalece, cresce o processo institucional instaurado. Legitimado o Orçamento Participativo enquanto mecanismo, garante os espaços e a construção de um processo democrático para o cidadâo, pressupondo, portanto, a manutenção do poder nas relações entre os agentes que dele participam. ${ }^{2}$

\section{A instauração da formação e o Orçamento Participativo}

A formação se define aqui como um “[...] processo de valorização social que não só envolve conhecimentos técnicos, mas também dimensões, atitudes e comportamentos inscritos num currículo oculto [...]"; "envolve também outros conhecimentos e saberes que são adquiridos e know-how através de experiências" 40 Orçamento Participativo enquanto meio de formação apresenta-se como um "instrumento capaz de transformar a sociedade, como um instrumento de democratização nas relações sociais na [...] sociedade". 5 E as relações sociais se dão justamente na participação nas rodadas do O.P., por exemplo, que se iniciam a cada ano, no mês de março, contando com representantes de diferentes áreas. Quanto à dinâmica do Conselho (COP), composto por agentes institucionais e agentes ${ }^{6}$ de diferentes regiões, uma das atribuições concerne a prestação de contas do ano anterior, bem como a dados sobre os critérios de priorização das demandas. De outro lado, outros agentes - conselheiros eleitos proporcionalmente pela população participante do processo - avaliam o plano de investimentos anual para a cidade, refletem posicionando-se criticamente, participam do Conselho do Orçamento Participativo (COP), incentivando os demais segmentos populares a participarem do processo.

BOURDIEU, Pierre. O poder simbólico. Rio de Janeiro: Bertrand Brasil, 1989, p. 15.

2 Bourdieu, op. cit., p. 196.

3 LOPES y ARTLLES. "Las relaciones entre formación y empleo: que formación, para que empleo?" In: Formação e trabalho e competência. Porto Alegre: EDIPUCRS, 1998, p. 187.

4 Lopes y Artilles, op. cit., p. 187.

5 TANGUY, Lucie. "Mudanças técnicas e recomposição dos saberes ensinados aos operários: do discurso à prática". In: Formação e trabalho e competência. Porto Alegre: EDIPUCRS, 1998, p. 148.

6 Agentes é o termo utilizado para designar as pessoas que participam do processo do Orçamento Participativo, representantes da Prefeitura, de partidos políticos, vereadores, ou comunidade em geral. 
As informações, as demandas recebidas, discutidas e votadas, as comissões estabelecidas, seminários, visitas e debates subsidiam os conselheiros que podem emitir atos, opiniões, apreciar e alterar em todo ou em parte o conjunto de aspectos totais ou parciais, bem como analisar incrementos, financiamentos, aplicações e políticas, constituindo-se tudo isso em práticas formativas.

Os conselheiros têm direitos e deveres. Entre eles o de votar e ser votado, ter voz e exigir o cumprimento das resoluções. Assim, a sistemática que configura o processo do Orçamento Participativo possibilita uma formação capaz de instaurar novas disposições junto aos habitantes de Porto Alegre, rompendo com o seu habitus ${ }^{7}$ relativo ao cidadão e cidadania.

\section{Algumas considerações finais}

As inúmeras práticas de cunho formativo desencadeadas pelo o.P. apóiam-se em ações informais ou nas "formações gerais, sem fornecimento de diplomas, apelando para a dinâmica dos atores, ação de tipo participativo, descentralização das estruturas e modificação da cadeia hierárquica de maneira a tomar a organização qualificante". ${ }^{8}$ Tais práticas formativas suscitam novos comportamentos que constituem um "novo perfil de cidadão" e passam pela capacidade de adquirir saberes sociais e, segundo Stroobants, esta noção "designa a capacidade para comunicar, entrar em acordo e tomar decisões, envolvendo saberes cuja aprendizagem é feita pelos indivíduos na vida social, [...]".?

Enfim, a emergência da noção de um cidadão que necessita de novas competências implica um conjunto de condições que abarcam diferentes níveis de uma trajetória. Tal trajetória consiste num processo que se consolida entre os agentes a partir das relações sociais. Formar um cidadão, capacitando-o através da participação, segundo Bourdieu, "é um exercício difícil porque requer a ruptura das aderências e das adesões mais profundas e mais inconscientes [...,". ${ }^{10}$

Estas rupturas garantem um novo modus operandi. ${ }^{11}$ Em resumo, busca-se demonstrar que essa evolução do cidadão no processo de formação através do o.P., instaura mudanças que identificamos através da obtenção de saberes e práticas formativas globalizantes construindo um poder dentro do campo, uma relação de força, um capital. ${ }^{12}$ Vislumbra-se também a constituição de uma noção de competência que, além de ser construída, é também compartilhada ${ }^{13}$

7 Habitus é um conhecimento adquirido e também um haver, um capital, uma disposição incorporada (BOURDIEU, Pierre. O poder simbólico. Rio de Janeiro: Bertrand Brasil, 1989, p. 61).

8 DUGUÉ, Elisabeth. "A gestão das competências; os saberes desvalorizados, o poder ocultado". In: Formaçāo e trabalho e competência. Porto Alegre: EDIPUCRs, 1998, p. 101.

" STROOBANTS, Marcelle. "Qualificações ou competências? Norma de geometria variável". In: Formação e trabalho e competência. Porto Alegre: EDIPUCRS, 1998, p. 81.

10 Bourdieu, op. cit., 1989, p. 55.

11 O modus operandi funciona em estado prático segurdo as normas da ciência. Faz com que se faça o que é preciso fazer no momento próprio gerando uma conduta adequada (Bourdieu, op. cit., 1989, p. 23).

Entende-se por capital uma forma de apropriação, aqui entendida como herança cultural adquirida por diferentes meios.

13 RIOS, Thereza. Ética e competência. São Paulo: Cortez, 1993, p. 79. 